\title{
Determinants of vitamin D status among Black and White low-income pregnant and non-pregnant reproductive-aged women from Southeast Louisiana
}

Natalie L. Burke' ${ }^{1}$, Emily W. Harville ${ }^{2}$, Jeffrey K. Wickliffe ${ }^{1}$, Arti Shankarr ${ }^{3}$, Maureen Y. Lichtveld ${ }^{1}$ and Michael L. McCaskill ${ }^{1 *}$ (D)

\begin{abstract}
Background: Vitamin D deficiency is a growing public health problem, with pregnant women being particularly vulnerable due to its influences on maternal and neonatal outcomes. However, there are limited data published about mediators of vitamin D status in Louisiana women. We aimed to assess the vitamin D status and its determinants among low-income pregnant and non-pregnant reproductive-aged women from southeast Louisiana.

Methods: This study was conducted using data from the Gulf Resilience on Women's Health (GROWH) research consortium cohort of pregnant and non-pregnant women which contained sociodemographic and dietary variables as well as blood and salivary element concentrations. Serum 25-hydroxy vitamin D was measured using an enzyme-linked immunosorbent assay in 86 pregnant and 98 non-pregnant women with an even distribution of race in both groups.

Results: The prevalence of deficient vitamin D levels in the total cohort (184 women) was 67\% and the mean 25(OH) vitamin $\mathrm{D}_{3}$ was $24.1 \mathrm{ng} / \mathrm{mL}$ (SD 10.7). Self-identifying as White, being pregnant, autumn season, young age and high exposure to tobacco smoke measured by cotinine were significantly associated with higher serum levels of vitamin D. Visiting Women and Infant clinics (WIC) was an important determinant in improving $25(\mathrm{OH})$ vitamin $\mathrm{D}_{3}$ levels for Black women but not for White women and concentrations varied more among Black women across seasons compared to White women.

Conclusions: Serum vitamin D levels are inadequate among a high proportion of Black and White low-income pregnant and reproductive-aged women living in Southeast Louisiana who were enrolled in the GROWH study. Black women who are over 35 years old and non-WIC participants constitute the subpopulation most at risk for vitamin D deficiency, especially during the winter. As an overall higher level of deficiency exists in Black women, if even small behavioral and dietary modifications are produced by WIC, this can lead to a comparatively greater improvement in vitamin D status in women from Southeast Louisiana who self-identify as Black.
\end{abstract}

Keywords: Vitamin D deficiency, Pregnancy, Women and infant clinics, Race, Sun exposure, Low income

\footnotetext{
* Correspondence: mmccaski@tulane.edu

${ }^{1}$ Department of Global Environmental Health Sciences, Tulane University

School of Public Health and Tropical Medicine, 1440 Canal Street, Suite 2100,

New Orleans, Louisiana 70112, USA

Full list of author information is available at the end of the article
}

(c) The Author(s). 2019 Open Access This article is distributed under the terms of the Creative Commons Attribution 4.0 International License (http://creativecommons.org/licenses/by/4.0/), which permits unrestricted use, distribution, and reproduction in any medium, provided you give appropriate credit to the original author(s) and the source, provide a link to the Creative Commons license, and indicate if changes were made. The Creative Commons Public Domain Dedication waiver (http://creativecommons.org/publicdomain/zero/1.0/) applies to the data made available in this article, unless otherwise stated. 


\section{Background}

Vitamin D is a nutrient and a prohormone that is gaining much attention in the medical literature due to the increasing understanding of its importance in health and disease. While vitamin D's classical role is in calcium and bone homeostasis, the vitamin $\mathrm{D}$ receptor is present in most tissues, including the placenta, and it is involved in various biological actions, including cell proliferation and differentiation in many target tissues [1-3]. In adults, vitamin $\mathrm{D}$ deficiency has been linked to a number of adverse health outcomes, including increased risk of cardiovascular disease, infection, cancer, and even mortality [3-7]. During pregnancy, vitamin D readily diffuses across the placental barrier, and fetal and newborn vitamin D status is almost entirely dependent on vitamin D from the mother [8-10]. Pregnancy-related adverse health outcomes associated with vitamin D deficiency include gestational hypertension/preeclampsia [11-13], gestational diabetes [14], small for gestational age (SGA) [15], cesarean delivery [16] and, most recently, autism in the infants [17]. Furthermore, low vitamin D levels are associated with depressive symptoms during pregnancy and postpartum depression [16].

"Vitamin D" refers to two biologically inactive precursors: cholecalciferol $\left(D_{3}\right)$ and ergocalciferol $\left(D_{2}\right)$. The $D_{3}$ form is obtained from synthesis in the skin under the influence of sunlight (ultraviolet B radiation (UVB); wavelengths 290-315) and dietary sources such as fatty fish and supplements. $D_{2}$ is synthetically derived through the ultraviolet irradiation of ergosterol from yeast and fungi, such as mushrooms, and used to make vitamin $\mathrm{D}_{2}$ supplements. Both vitamin $\mathrm{D}_{3}$ and vitamin $\mathrm{D}_{2}$ are converted in the liver to circulating 25-hydroxyvitamin $\mathrm{D}_{3}[25(\mathrm{OH})$ $\mathrm{D}_{3}$ ], also known as calcidiol [1]. Therefore, 25(OH) $\mathrm{D}_{3}$ levels reflect the dietary input and/or cutaneous production of vitamin $D_{3}$. This metabolite is not active but serves as a circulating reservoir that is further metabolized mostly in the kidneys into the active form, calcitriol $\left[1,25(\mathrm{OH}) \mathrm{D}_{3}\right]$. Although 1, 25-Dihydroxyvitamin $\mathrm{D}_{3}$ is the biologically active form of vitamin $D, 25(\mathrm{OH}) \mathrm{D}_{3}$ is the major form of circulating vitamin $\mathrm{D}$ and is highly stable for analysis from stored serum or plasma. This biological stability is due to its long half-life of about 2 to 3 weeks in serum, its high serum level, and non-tight regulation of 25 $(\mathrm{OH}) \mathrm{D}_{3}$ formation [18-21]. Thus, most of the current literature uses $25(\mathrm{OH}) \mathrm{D}_{3}$ as the biomarker of overall vitamin D status.

Ultra-violet radiation mediated conversion of 7-dehydrocholesterol into vitamin $D_{3}$ in the epidermal layer of the skin is the primary determinant of vitamin $\mathrm{D}$ status in most humans. The efficiency of the dermal conversion of 7-dehydrocholesterol is a function of type of skin pigmentation and the solar zenith angle which depends on latitude, season, and time of the day
[22]. The skin pigment melanin limits the rate at which UVB radiation transmits through the skin, which reduces 7-dehydrocholesterol conversion. Consequently, individuals with darker skin pigment require more sun exposure to produce similar amounts of vitamin $\mathrm{D}_{3}$ as compared to those with less pigmented skin $[22,23]$. It has been shown that persons with deeply pigmented skin and those living in high latitude locations during the winter season are particularly at risk of vitamin D deficiency [2, 22, 24].

Dietary sources of vitamin D generally contain modest amounts of the vitamin [3, 9]. Foods that naturally contain vitamin D include fatty fish, mushrooms, and egg yolk. Fortified foods include milk, orange juice, yogurts, butter, margarine, cheeses, and breakfast cereal $[1,8,22]$. Supplementation such as prenatal multi-vitamins containing vitamin $\mathrm{D}_{3}$ or $\mathrm{D}_{2}$, or of vitamins containing $\mathrm{D}_{3}$ or $\mathrm{D}_{2}$ alone can directly influence systemic vitamin $\mathrm{D}$ levels. While the administration of prenatal vitamins is primarily to maintain healthy levels of folic acid, iron, and calcium, most of prenatal vitamins also contain around $400 \mathrm{IU}-600 \mathrm{IU}$ of vitamin $\mathrm{D}_{3}$ [25]. Prenatal supplementation may partially explain why pregnant women tend to have higher $25(\mathrm{OH}) \mathrm{D}_{3}$ levels compared to non-pregnant women [24]. Additional "influencing factors" that have been associated with vitamin D deficiency include obesity, high education and low age $[2,26]$.

While vitamin $\mathrm{D}$ deficiency is an important public health problem [26, 27], to our knowledge there is only one published research article describing vitamin $\mathrm{D}$ health in pre or post partum women living in coastal communities in states bordering the Gulf of Mexico [28]. Data shows that reproductive-aged women are vulnerable to vitamin D deficiency, which is associated with many adverse reproductive outcomes [3, 26-28]. Dietary intake and/or supplementation is crucial to maintaining a healthy vitamin $\mathrm{D}$ status when vitamin $\mathrm{D}_{3}$ synthesized from sunlight is limited. Hence, the goal of this project was to provide a greater understanding of circulating vitamin $D_{3}$ levels and to determine related risk factors such as heavy metal exposure, cigarette smoke exposure, age and race, in a population at high risk of vitamin D deficiency [29].

\section{Methods}

\section{Study design and population}

This study is embedded in the Transdisciplinary Research Consortium for Gulf Resilience on Women's Health (GROWH). GROWH is a National Institute of Health-funded research consortium designed to address health issues of concern to the residents of the Gulf of Louisiana parishes affected by the Deepwater Horizon (DWH) oil spill, focusing on women of reproductive age [29-31]. The long-term goal of GROWH is to examine the causes of adverse reproductive outcomes and 
ultimately develop interventions to improve those outcomes. GROWH supported population-based and laboratory research to develop the scientific evidence base needed to promote health and well-being for people living along the Gulf Coast who are at greatest risk for potential adverse physical, psychological and behavioral health effects.

Between January 2011 and December 2016, approximately 1700 women who fulfilled the inclusion criteria of being 18-45 years old or pregnant and older than 45 , living in one of the affected parishes at the time of the oil spill (2010), singleton pregnancy, and English-, Spanish-, or Vietnamese-speaking were recruited from prenatal Women, Infants, and Children (WIC) clinics, primary care clinics as well as community organizations in Southern Louisiana. The Special Supplemental Nutrition Program for WIC serves low-income pregnant and postpartum women and provides nutrition education and food vouchers. WIC programs do not provide direct prenatal care services but do reach a large proportion of low-income women during the perinatal period [32].

The recruitment of this population was done through convenience sampling at a wide range of health and community facilities, which likely makes it more representative of exposure and effects in the community compared to studies of litigants or those referred for clinical evaluation [30,33]. Although details of prenatal vitamin use were not collected, all women received prenatal care and standard prenatal care calls for prescription of prenatal vitamins (data not shown), which typically contain $400 \mathrm{IU}-600 \mathrm{IU}$ vitamin D $[22,25]$. In previous studies of similar populations $>90 \%$ of women reported regularly taking prenatal vitamins [34].

\section{Sample}

The current study involved a sub-cohort of the overall 1700 GROWH cohort. The sample consisted of 91 pregnant women (48 Black and 43 White) and 100 non-pregnant women of reproductive age (50 Black and 50 White) who were randomly selected based on two inclusion criteria (Fig.1). The sample was limited to those with measured elemental concentrations (Lead $[\mathrm{Pb}]$, Mercury $[\mathrm{Hg}]$, Cadmium $[\mathrm{Cd}]$ ) and reported race data. The race category "Black" consists of non-Hispanic Black as well as Hispanic, Black women. The race category "White" consists of non-Hispanic White as well as Hispanic, White women.

Circulating blood serum 25(OH) vitamin D concentrations were determined for 100 pregnant women and 100 non-pregnant women. Participants were randomly selected

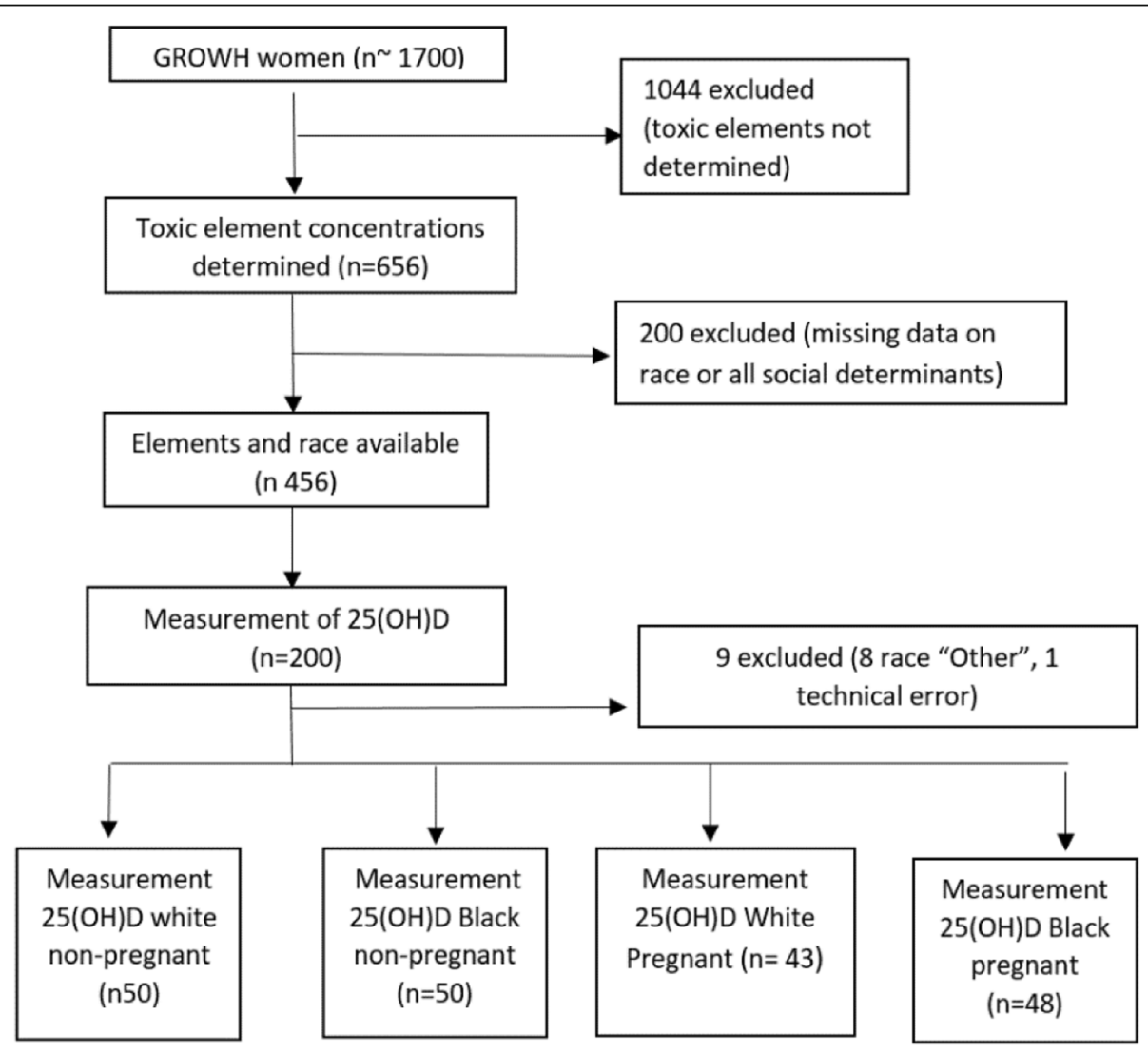

Fig. 1 A flow chart illustrating the inclusion and exclusion criteria of the study population selection 
within racial groups to provide an even distribution in the pregnant and non-pregnant groups. Nine measurements were excluded from the study due to incorrect race categorization and one case of vitamin $\mathrm{D}$ concentration below the level of detection due to a lab error.

\section{Biomarkers}

Maternal venous blood was drawn at the same visit as the interview and questionnaire, at the convenience of the participants. All blood samples were processed within $12 \mathrm{~h}$, and aliquots of serum or plasma were frozen at $-70^{\circ}$ Celsius until analysis.

Biomarker analyses of elements $\mathrm{Pb}, \mathrm{Cd}, \mathrm{Hg}$ from serum and salivary cotinine (a biomarker for tobacco use) were performed for a random sample of pregnant and non-pregnant women of the GROWH cohort. Metals were analyzed using inductively coupled plasma-mass spectrometry (ICP-MS). Standards and blank tubes underwent the same digestion procedures as the samples. The concentration of each metal analyzed in whole blood samples is expressed as micrograms per liter or micrograms per deciliter where appropriate [35].

Elements were investigated as continuous as well as dichotomous variables. None of the women in this sample had levels exceeding CDC or OSHA guidelines for lead or cadmium ( $5 \mu \mathrm{g} / \mathrm{dL}$ and five $\mu \mathrm{g} / \mathrm{L})$, so we choose to dichotomize based on median values. For mercury, we adhered to the recommendations of the US Environmental Protection Agency (EPA) of $5.8 \mu \mathrm{g} / \mathrm{L}$ for cord blood [36, 37].

Cotinine was investigated as a continuous variable and as a dichotomous variable to distinguish women with low tobacco smoke exposure from women with high levels of tobacco smoke exposure, using the $12.9 \mathrm{ng} / \mathrm{mL}$ cutoff for pregnant women determined by Stragierowics et al., 2013 [38]. Cotinine represents total tobacco exposure, meaning environmental tobacco smoke exposure as well as from first-hand tobacco smoking.

\section{Assessment of circulating $25(\mathrm{OH})$ vitamin $\mathrm{D}_{3}$ concentration}

For this study, the GROWH serum samples collected between 2011 and 2016 were thawed, and 25-Hydroxyvitamin $\mathrm{D}\left[25(\mathrm{OH}) \mathrm{D}_{3}\right]$, which is highly stable for analysis was measured in serum. Although serum vitamin D levels have been correlated with many diverse health endpoints, Vieth et al. 2006 emphasizes that often the criteria for vitamin D adequacy are promulgated from randomized clinical trials investigating associations between vitamin $\mathrm{D}$ and bone health. Garland et al. 2014 concluded that serum 25(OH) vitamin $\mathrm{D}_{3}$ concentrations greater than $30 \mathrm{ng} / \mathrm{mL}$ resulted in lower all-cause mortality than concentrations less than or equal to $30 \mathrm{ng} / \mathrm{mL}(p<.01)$ [3]. Acknowledging the growing body of evidence that vitamin $\mathrm{D}_{3}$ levels $>30 \mathrm{ng} /$
$\mathrm{mL}(75 \mathrm{nmol} / \mathrm{L})$ are required for optimum overall health $[3,7,39]$, we adhered to this as a cutoff measurement.

This measurement was performed using the Total 25-OH vitamin $\mathrm{D}_{3}$ ELISA analysis kit from Crystal Chem (Downers Grove, Illinois, U.S.A.), following the manufacturer's recommended concentrations and procedures. Subsequently, 25(OH) vitamin $\mathrm{D}_{3}$ concentrations were determined using GraphPad Prizm (7.0) software. The total $25(\mathrm{OH})$ vitamin $\mathrm{D}_{3}$ calibration curve was constructed by plotting the mean absorbance values for each standard on the Y-axis against the corresponding $25(\mathrm{OH})$ vitamin $\mathrm{D}_{3}$ concentration on the $\mathrm{X}$-axis. A four-parameter logistic (4-PL) curve was used for evaluation.

\section{Determinants of vitamin D status}

We investigated dietary, socioeconomic, and environmental factors for associations with vitamin D (Fig. 2); race, season at blood sampling, pregnancy, age, income class, education level, enrollment in WIC clinics, pre-pregnancy BMI, smoking levels and alcohol consumption, and fish and seafood intake.

Seasons were calculated based on interview dates and were defined as follows: spring (March through May), summer (June through August), autumn (September through November), winter (December through February). WIC status was determined based on the name of the clinic of enrollment.

\section{Measurement instruments Demographics}

A short series of questions examining the demographics and social status of the study participants was created for the GROWH study. Questions chosen from the scale included those investigating race, age, BMI, income levels, education levels, and residence.

\section{Smoking and alcohol use}

Questions regarding health behavior and access to prenatal care for the GROWH study were adapted from PRAMS, the Pregnancy Risk Assessment Monitoring [40]. Smoking status was based on the question: "In the three months before you got pregnant, how many cigarettes did you smoke on an average day? "Alcohol use was based on the question: "During the three months before you got pregnant, how many alcoholic drinks did you have in an average week?"

\section{Fish consumption}

The Fish Food Frequency Questionnaire by Mina et al. 2007, was adapted for local fish [41, 42]. This study focused on fish and seafood known to contain relatively high vitamin $\mathrm{D}$ levels $[1,8,22]$, and those most frequently consumed by the study population. Fish 


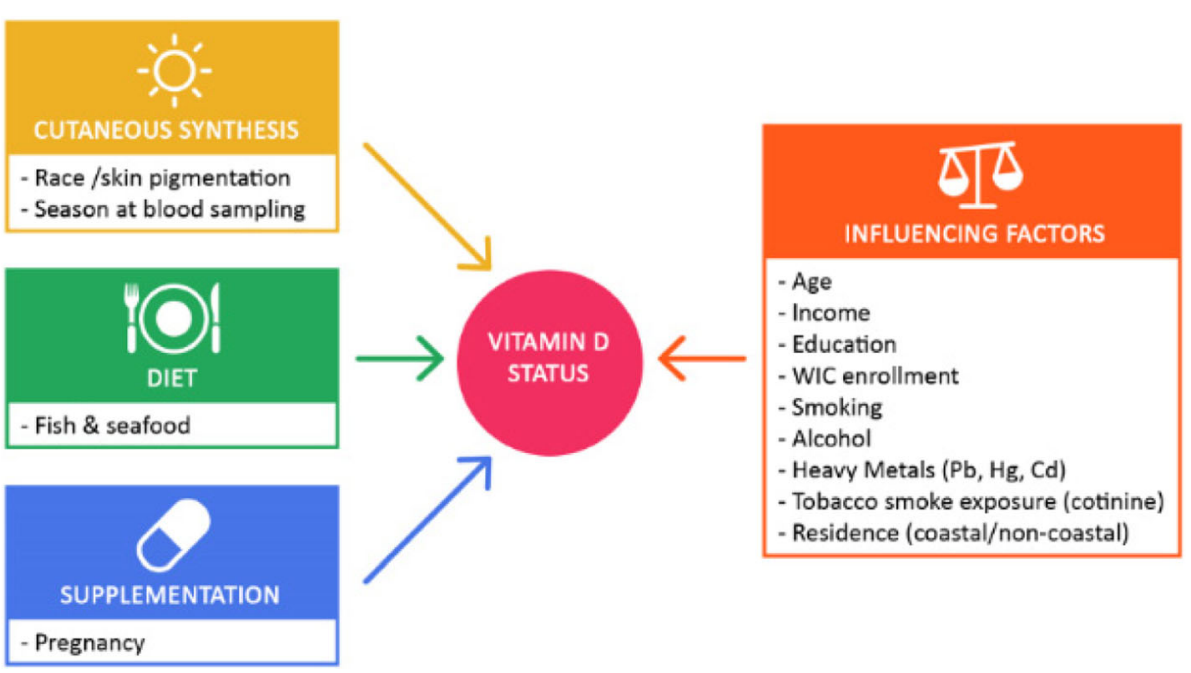

Fig. 2 Determinants investigated for associations with serum vitamin $D_{3}$ levels

considered to be high in vitamin $\mathrm{D}$ were: canned tuna, canned salmon, tuna (not canned), salmon (not canned), White trout, cod, Spanish mackerel, king mackerel, mahi-mahi, and swordfish. These fish were all grouped into the category fatty fish meaning that if a participant ate any of the before mentioned fish, it would add to the frequency of fatty fish consumption. The frequency was multiplied by the ounces of fish the women regularly ate per serving. Fatty fish consumption was analyzed as a categorical variable $(0 \mathrm{oz}$ per week, $0-3.5 \mathrm{oz}$ per week, more than $3.5 \mathrm{oz}$ per week) and as a continuous variable. The most frequently consumed fish and seafood were analyzed as a continuous variable, looking at mean servings per week.

\section{Pre-pregnancy body mass index (BMI)}

Body mass index was based on self-reported height at recruitment and pre-pregnancy self-reported weight $(\mathrm{kg} /$ m2) (underweight $(<18.5)$, normal weight (18.5-24.99), overweight (25-29.99), and obese (>30).

\section{Statistical analysis}

The Statistical Package for Social Sciences (SPSS Inc. version 22) was used for data analysis. First, all data were analyzed descriptively via univariate analysis. Vitamin D status was expressed as a categorical variable to assess the prevalence and degree of deficiency among the entire study population and as a continuous variable (means + standard deviations) for bivariate analysis and linear regression. The distributions for serum vitamin D concentrations, heavy metals levels, and fish and seafood consumption were explored by assessing normality plots and by conducting tests of normality including the Kolmogorov-Smirnov test and the Shapiro-Wilk test.
After serum vitamin D concentrations showed a non-normal distribution, outliers were identified by adding or subtracting twice the standard deviation $(2 \times$ $12.9)$ to the mean vitamin $D$ levels $(25.6 \mathrm{ng} / \mathrm{mL})$. Seven outliers with $25(\mathrm{OH}) \mathrm{D}_{3}$ levels ranging from $53 \mathrm{ng} / \mathrm{mL}$ to $75 \mathrm{ng} / \mathrm{mL}$ were removed after which the distribution of vitamin D levels became normal according to normality plots and tests of normality. Six of the seven outliers where White. Five where pregnant, and four had a coastal zip code. Heavy metals and fish and seafood consumption were non-normally distributed and were analyzed using non-parametric tests.

Second, bivariate associations between the dependent variable $25(\mathrm{OH}) \mathrm{D}_{3}$ and categorical variables such as race, income, age were examined using independent sample t-test and one-way ANOVA (with Tukey's post hoc test). Kruskal- Wallis Test or Mann-Whitney U test was used for nonparametric analyses. Associations of vitamin D with continuous variables was done using Pearson correlation and Spearman correlation if the continuous variable was not normally distributed. Due to the established relationship between race and vitamin $D$ status, we chose to investigate interactions between race and the other covariates. To investigate interactions between two independent variables on vitamin D levels, a factorial design (two-way ANOVA) was used.

Predictor variables associated with the dependent variable at a statistically significant level $(p<0.05)$ were entered in the final multiple regression model multivariate model. Third, multiple linear regression was used to estimate the association between $25(\mathrm{OH}) \mathrm{D}_{3}$ and the included predictor variables. The standardized beta coefficient and 95\% confidence intervals were reported. 


\section{Results}

Of the GROWH 2011-2016 participant cohort, we analyzed the characteristics of a sample of 184 women (84 pregnant, 100 non-pregnant). Characteristics of the study population are presented in Table 1. Fish and seafood most frequently consumed among this population were shrimp followed by canned tuna, crab, catfish, crayfish and tilapia (data not shown).

\section{Population characteristics by pregnancy status}

The characteristics that differed significantly between pregnant and non-pregnant women included age, WIC participation, self-reported smoking levels, and proximity to the coast. Pregnant women who were younger were not recruited through WIC clinics as often as non-pregnant women. Younger study participants reported lower rates of smoking cigarettes and most did not live close to the coast. Although pregnant women reported less smoking behavior, cotinine concentrations were similar between the pregnant and non-pregnant group.

\section{Population characteristics by race}

Between Black and White women, there was a difference in self-reported smoking levels with White women smoking more than Black women. Cotinine levels confirm this result.

Vitamin D status and mean serum $25(\mathrm{OH})$ vitamin $\mathrm{D}_{3}$ levels are presented in Table 2 . Overall, $38 \%$ of the women had serum $25(\mathrm{OH}) \mathrm{D}_{3}$ concentrations $<20 \mathrm{ng} / \mathrm{mL}$ (severe deficiency) and 29\% had concentrations between 21 and $30 \mathrm{ng} / \mathrm{mL}$ (moderate deficiency). Levels below $20 \mathrm{ng} / \mathrm{mL}$ were much more prevalent in Black women than White women (52\% vs. $23 \%$ ). In pregnant women, $26 \%$ had levels $<20 \mathrm{ng} / \mathrm{mL}$ compared to $49 \%$ in the non-pregnant group. Women sampled in the autumn had lower levels of vitamin D deficiency than other seasons (16\%).

Interestingly, vitamin D deficiency was seen less in the high cotinine group. Other factors such as income level, WIC participation, education level, self-reported smoking levels, exposure to heavy metals, fatty fish consumption, and proximity to coast did not show any relationship with vitamin $\mathrm{D}$ status. The overall mean serum $25(\mathrm{OH}) \quad \mathrm{D}_{3}$ level was $24.1 \mathrm{ng} / \mathrm{mL}$. Vitamin $\mathrm{D}$ levels varied strongly between Black and White women with Black women having lower concentrations than White women (20.7 vs. $27.6 \mathrm{ng} / \mathrm{mL}$ ) Serum 25(OH) $\mathrm{D}_{3}$ levels were significantly higher among pregnant women compared to non-pregnant women (25.9 vs. 22.6; $P$ $=.037)$. Other determinants that were associated with higher levels of vitamin D included being sampled in the autumn, having a young age, and belonging to the high cotinine group. Correlation tables revealed that vitamin $\mathrm{D}$ was not correlated with any of the heavy metals but was positively associated with cotinine levels as a continuous variable (Table 3). Furthermore, vitamin D was not associated with any of the most frequently consumed fish (Table 4).

Multivariable predictors of 25(OH)D levels (continuous) are presented in Table 5. Race was the strongest predictor for mean 25(OH)D levels followed by season, age, and pregnancy respectively. The covariates that interacted with race in determining mean $25(\mathrm{OH}) \mathrm{D}_{3}$ levels included age and WIC clinic use (Figs. 3 and 4). For all the age categories, except 30-35, White women had a significantly higher mean serum $25(\mathrm{OH}) \mathrm{D}_{3}$ than Black women (Fig. 3 ). The sudden dip in vitamin D in White women in age category 30-35 brings mean serum $25(\mathrm{OH}) \mathrm{D}_{3}$ levels very close to that of Black women (20.6 vs. 20.9 respectively). Women in the youngest age group had the highest vitamin D levels in White as well as Black women $(31.8 \mathrm{ng} / \mathrm{mL}$ vs. $23.0 \mathrm{ng} / \mathrm{mL})$. For White women, those in age category 30-35 had the lowest vitamin D levels $(20.6 \mathrm{ng} / \mathrm{mL})$ while it was age category $>35$ for Black women $(13.6 \mathrm{ng} / \mathrm{mL})$. The largest difference in mean serum 25(OH) $D_{3}$ levels between Black and White women is observed in age category $>35(13.6 \mathrm{ng} / \mathrm{mL}$ Black vs. $27.4 \mathrm{ng} / \mathrm{mL}$ White; $p<0.001)$. Post-hoc analysis showed that all Black women in the age category $>35$ years were non-pregnant. In the White group aged over 35, there were three pregnant women versus 13 non-pregnant.

While being enrolled in the WIC program did not independently influence serum $25(\mathrm{OH}) \mathrm{D}_{3}$ levels, it does influence the effect of race on vitamin D status $(p=.017)$ (Fig. 4). White women selected from WIC clinics did not have significantly different mean serum vitamin $\mathrm{D}$ levels than White women not from WIC clinics $(27.2 \mathrm{ng} / \mathrm{mL}$ vs. $28.9 \mathrm{ng} / \mathrm{mL}$ respectively). However, Black women from WIC clinics had significantly higher mean vitamin D levels than those not from WIC clinics $(22.5 \mathrm{ng} / \mathrm{mL}$ vs. $16.3 \mathrm{ng} /$ $\mathrm{mL})$. This observation was not due to the influence of pregnancy (Black pregnant and non-pregnant women were enrolled at WIC clinics in similar proportions).

Predictor variables that influenced mean serum $25(\mathrm{OH}) \mathrm{D}_{3}$ independent of race include pregnancy, season, and cotinine status (Table 5). Overall, pregnant women had significantly higher mean serum $25(\mathrm{OH}) \mathrm{D}_{3}$ levels than non-pregnant women; however, when race is taken into consideration, we see that there was only a significant difference in mean serum $25(\mathrm{OH}) \mathrm{D}_{3}$ levels between White pregnant and White non-pregnant women. While the effect of season on mean serum $25(\mathrm{OH}) \mathrm{D}_{3}$ did not significantly interact with the effect of race on mean $25(\mathrm{OH}) \mathrm{D}_{3}(p=0.067)$, a trend can still be observed (Fig. 5); Seasonality did not affect vitamin D status for White women $(p=0.130)$, but it did for Black women $(p=.030)$. For Black women, the highest mean serum $25(\mathrm{OH}) \mathrm{D}_{3}$ levels were found in the autumn (26.5 $\mathrm{ng} / \mathrm{mL})$ and the lowest in the winter $(15.0 \mathrm{ng} / \mathrm{mL})$. 
Table 1 Characteristics of all women, pregnant women vs. non-pregnant women and Black vs White women

\begin{tabular}{|c|c|c|c|c|c|c|c|}
\hline Characteristics & $\begin{array}{l}\text { All women } \\
n=184^{*}(\%)\end{array}$ & $\begin{array}{l}\text { Pregnant women } \\
n=84^{*}(\%)\end{array}$ & $\begin{array}{l}\text { Non-pregnant women } \\
n=100^{*}(\%)\end{array}$ & P) & $\begin{array}{l}\text { White women } \\
n=87^{*}(\%)\end{array}$ & $\begin{array}{l}\text { Black women } \\
n=97^{*}(\%)\end{array}$ & $\left.P^{a}\right)$ \\
\hline Race & & & & 0.623 & & & \\
\hline Black & 97 (53\%) & 47 (55\%) & $50(51 \%)$ & & - & - & \\
\hline White & 87 (47\%) & $39(45 \%)$ & $48(49 \%)$ & & - & - & \\
\hline Season & & & & 0.263 & & & 0.199 \\
\hline Spring & $31(18 \%)$ & $14(17 \%)$ & 17 (19\%) & & 14(17\%) & 17(19\%) & \\
\hline Summer & 84 (49\%) & 35 (43\%) & 49 (54\%) & & $34(42 \%)$ & $50(55 \%)$ & \\
\hline Autumn & $43(25 \%)$ & $24(29 \%)$ & 19 (21\%) & & $26(32 \%)$ & 17(19\%) & \\
\hline Winter & $14(8 \%)$ & $9(11 \%)$ & $5(6 \%)$ & & 7(9\%) & $7(8 \%)$ & \\
\hline Fish consumption & & & & 0.663 & & & 0.206 \\
\hline 0 oz/week & $50(27 \%)$ & 25 (29\%) & $25(26 \%)$ & & 29 (33\%) & $21(22 \%)$ & \\
\hline 0-3.5 oz/week & 90 (49\%) & 39 (45\%) & $51(52 \%)$ & & $39(45 \%)$ & 51 (53\%) & \\
\hline > 3.5 oz/week & $44(24 \%)$ & $22(26 \%)$ & $22(22 \%)$ & & 19 (22\%) & $25,926 \%)$ & \\
\hline Pregnant & & & & & & & 0.623 \\
\hline no & $98(53 \%)$ & - & - & & $48(55 \%)$ & $50(52 \%)$ & \\
\hline yes & $86(47 \%)$ & - & - & & 39 (45\%) & 47 (48\%) & \\
\hline Age & & & & 0.020 & & & 0.952 \\
\hline $18-25$ & $68(40 \%)$ & $38(47 \%)$ & 30 (33\%) & & 31 (39\%) & 37 (40\%) & \\
\hline$>25-30$ & $46(27 \%)$ & $25(31 \%)$ & $21(23 \%)$ & & $21(26 \%)$ & $25(27 \%)$ & \\
\hline$>30-35$ & 35 (20\%) & $12(15 \%)$ & $23(25 \%)$ & & $16(20 \%)$ & 19 (21\%) & \\
\hline$>35$ & $23(13 \%)$ & $6(7.4 \%)$ & 17 (19\%) & & $12(15 \%)$ & $11(12 \%)$ & \\
\hline BMI & & & & $0.243^{*}$ & & & $0.618^{*}$ \\
\hline$<18.5$ & $2(1 \%)$ & $2(2 \%)$ & $0(0 \%)^{*}$ & & $0(0 \%)^{*}$ & $2(2 \%)$ & \\
\hline $18.5-24.99$ & 47 (26\%) & $24(30 \%)$ & $23(24 \%)$ & & $22(27 \%)$ & $25(26 \%)$ & \\
\hline $25-29.99$ & $43(24 \%)$ & $16(20 \%)$ & $27(28 \%)$ & & $20(24 \%)$ & $23(24 \%)$ & \\
\hline$>30$ & $86(48 \%)$ & $39(48 \%)$ & $47(49 \%)$ & & 41 (49\%) & $45(47 \%)$ & \\
\hline Income & & & & 0.899 & & & 0.417 \\
\hline$<\$ 10,000$ & $85(50 \%)$ & $38(48 \%)$ & $47(52 \%)$ & & $35(46 \%)$ & $50(54 \%)$ & \\
\hline$>\$ 10,000-\$ 30,000$ & $56(33 \%)$ & $27(34 \%)$ & $29(32 \%)$ & & $26(34 \%)$ & $30(32 \%)$ & \\
\hline$>\$ 30,000$ & $29(17 \%)$ & $14(18 \%)$ & $15(17 \%)$ & & $16(21 \%)$ & $13(14 \%)$ & \\
\hline WIC & & & & 0.003 & & & 0.684 \\
\hline yes & $121(69 \%)$ & $50(58 \%)$ & $71(79 \%)$ & & 59 (70\%) & $62(67 \%)$ & \\
\hline no & $55(31 \%)$ & $36(42 \%)$ & 19 (21\%) & & $25(30 \%)$ & $30(33 \%)$ & \\
\hline Education level & & & & 0.793 & & & 0.641 \\
\hline High school or less & $96(53 \%)$ & $45(54 \%)$ & $51(52 \%)$ & & $47(55 \%)$ & 49 (51\%) & \\
\hline Some college/Associate's degree & 77 (42\%) & $34(40 \%)$ & $43(44 \%)$ & & $35(41 \%)$ & $42(43 \%)$ & \\
\hline College graduate or higher & $9(5 \%)$ & $5(6 \%)$ & $4(4 \%)$ & & $3(4 \%)$ & $(6 \%)$ & \\
\hline Smoking level & & & & 0.000 & & & 0.000 \\
\hline nonsmoker & $114(64 \%)$ & $54(66 \%)$ & $60(63 \%)$ & & $41(50 \%)$ & 73 (77\%) & \\
\hline former & $16(9 \%)$ & $14(17 \%)$ & $2(2 \%)$ & & $11(13 \%)$ & $5(5 \%)$ & \\
\hline $1-10$ cigs/day & 39 (22\%) & $14(17 \%)$ & $25(26 \%)$ & & $23(28 \%)$ & $16(17 \%)$ & \\
\hline$>=11 \mathrm{cigs} /$ day & $8(5 \%)$ & $0(0 \%)^{*}$ & $8(8 \%)$ & & 7 (9\%) & $1(1 \%)$ & \\
\hline Cotinine & & & & 0.547 & & & 0.013 \\
\hline High (> $12.9 \mathrm{ng} / \mathrm{mL}$ ) & $21(29 \%)$ & $12(27 \%)$ & $9(33 \%)$ & & 15(43\%) & $6(16 \%)$ & \\
\hline
\end{tabular}


Table 1 Characteristics of all women, pregnant women vs. non-pregnant women and Black vs White women (Continued)

\begin{tabular}{|c|c|c|c|c|c|c|c|}
\hline Characteristics & $\begin{array}{l}\text { All women } \\
n=184^{*}(\%)\end{array}$ & $\begin{array}{l}\text { Pregnant women } \\
n=84^{*}(\%)\end{array}$ & $\begin{array}{l}\text { Non-pregnant women } \\
n=100^{*}(\%)\end{array}$ & P) & $\begin{array}{l}\text { White women } \\
n=87^{*}(\%)\end{array}$ & $\begin{array}{l}\text { Black women } \\
n=97^{*}(\%)\end{array}$ & $\left.P^{a}\right)$ \\
\hline Low $(<12.9 \mathrm{ng} / \mathrm{mL})$ & $51(71 \%)$ & $33(73 \%)$ & $18(67 \%)$ & & $20(57 \%)$ & 31 (84\%) & \\
\hline Lead (Median) & & & & 0.052 & & & 0.596 \\
\hline High $(>0.48 \mu \mathrm{g} / \mathrm{dL})$ & $85(50 \%)$ & $30(41 \%)$ & $55(56 \%)$ & & $39(52 \%)$ & $47(48 \%)$ & \\
\hline Low $(<0.48 \mu \mathrm{g} / \mathrm{dL})$ & $86(50 \%)$ & 43 (59\%) & $43(44 \%)$ & & $36(48 \%)$ & $50(52 \%)$ & \\
\hline Mercury & & & & 0.215 & & & 0.126 \\
\hline High $(>5.8 \mu \mathrm{g} / \mathrm{L})$ & 89 (52\%) & $42(58 \%)$ & 47 (48\%) & & $44(59 \%)$ & $45(47 \%)$ & \\
\hline Low $(<5.8 \mu \mathrm{g} / \mathrm{L})$ & $82(48 \%)$ & $31(43 \%)$ & $51(52 \%)$ & & $31(41 \%)$ & $51(53 \%)$ & \\
\hline Cadmium (median) & & & & 0.058 & & & 0.381 \\
\hline $\operatorname{High}(>.47 \mu \mathrm{g} / \mathrm{L})$ & $87(51 \%)$ & $31(42 \%)$ & $56(57 \%)$ & & $41(55 \%)$ & $46(48 \%)$ & \\
\hline Low $(<.47 \mu g / L)$ & $84(49 \%$ & $42(58 \%)$ & $42(43 \%)$ & & $34(45 \%)$ & $50(52 \%)$ & \\
\hline Proximity to coast & & & & 0.012 & & & 0.014 \\
\hline Zip code proximal to coast & $30(18 \%)$ & $8(10 \%)$ & $22(25 \%)$ & & $21(25 \%)$ & $9(11 \%)$ & \\
\hline Further from coast & $139(82 \%)$ & $72(90 \%)$ & $67(75 \%)$ & & $63(75 \%)$ & $76(89 \%)$ & \\
\hline
\end{tabular}

*Data may not add to total amounts due to missing data

p) The $p$-values refer to differences between pregnant and non-pregnant women, using Pearson chi-square tests (Bold type indicates significance $p<0.05$ $\mathrm{p}^{\mathrm{a}}$ ) The $p$-values refer to differences between White and Black women, using Pearson chi-square tests (Bold type indicates significance $p<0.05$ )

${ }^{*}$ Chi-square test not reliable if cell has frequency of 0

In the summer and winter White women had significantly higher mean serum $25(\mathrm{OH}) \mathrm{D}_{3}$ levels as compared to Black women.

Income, education, self-reported smoking levels, lead, mercury, cadmium exposure, and coastal residence had no statistically significant influence on the effect of race on vitamin $\mathrm{D}$ status, nor did they independently predict mean serum $25(\mathrm{OH}) \mathrm{D}_{3}$ levels.

\section{Discussion}

Over one-third of all the women included in the study (38\%) had severely deficient serum levels of vitamin D $(<20 \mathrm{ng} / \mathrm{mL}), 67 \%$ had levels below $30 \mathrm{ng} / \mathrm{mL}$ and the overall mean serum concentration was $24.1 \mathrm{ng} / \mathrm{mL}$, suggesting that for a significant portion of low-income women living in southern Louisiana who were enrolled in the GROWH study, sun exposure, dietary intake, and supplementation do not provide adequate vitamin D support. These findings are similar to those of a National Health and Nutrition Examination Survey (NHANES), representative of 62 million US women between 2001 and 2006, showing that overall, $41 \%$ of US women aged 13-44 years had vitamin D deficiency $(<20 \mathrm{ng} / \mathrm{mL})$, and $78 \%$ had levels $<30 \mathrm{ng} / \mathrm{mL}$. The mean serum $25(\mathrm{OH}) \mathrm{D}$ concentration was $23.6 \mathrm{ng} / \mathrm{mL}$ [24].

The variables associated with mean $25(\mathrm{OH}) \mathrm{D}_{3}$ levels in this study were: race, season, pregnancy, tobacco exposure measured by salivary cotinine level and age. Pregnancy, self-identifying as White, autumn season, young age and high exposure to tobacco smoke were associated with higher serum levels of vitamin D.

\section{Skin's synthesis due to sun exposure}

Cutaneous synthesis of vitamin $\mathrm{D}_{3}$ is mediated by skin pigmentation, latitude, season, time of day, and dermal exposure to the sun. The prevalence of vitamin D deficiency in this study was twice as high for Black women compared to White women, confirming prior studies that report much lower vitamin D levels among reproductive-aged women with more pigmented skin $[10,16,24,26,43]$. Deeply pigmented skin is very effective in absorbing UVB radiation and thus reducing the cutaneous synthesis of vitamin $\mathrm{D}_{3}[3]$ and is likely the major cause of the observed differences by race. It is possible that vitamin D status contributes to the reproductive health gap that exists between Black and White women, and improving vitamin $\mathrm{D}$ status in persons with deeply pigmented skin might help narrow this disparity $[10,16]$. It is worth mentioning that research suggests that race-dependent differences in vitamin $\mathrm{D}$ binding protein (VDBP) could explain differences in total vitamin D levels with Blacks having less total vitamin D due to lower levels of VDBP [44]. However, Aloia et al. 2015 showed that only $4 \%$ of the observed race-associated differences in total $25(\mathrm{OH}) \mathrm{D}_{3}$ could be attributed to race dependent VDBP serum variations [45].

Seasonality affects vitamin D levels, with winter generally being the season with the lowest levels and summer the season with the highest $[43,46,47]$. During the winter months, sunlight is filtered at a more oblique angle, decreasing the ultraviolet radiation. Our study, however, showed that women sampled in autumn had the highest mean $25(\mathrm{OH}) \mathrm{D}_{3}$ levels. This observation coincides with 
Table 2 Vitamin D status (severe deficiency/moderate deficiency) and mean 25(OH)D levels stratified by characteristics including significance values for bivariate analyses

\begin{tabular}{|c|c|c|c|c|c|}
\hline Characteristics & Severe deficiency $(<20 \mathrm{ng} / \mathrm{mL})$ & Moderate deficiency (21-30 ng/mL) & $p$ & Mean 25(OH)D levels (SD) & $P^{a}$ \\
\hline Total & $38 \%$ & $29 \%$ & & $24.1(10.7)$ & \\
\hline Race & & & 0.000 & & 0.000 \\
\hline Black & $52 \%$ & $29 \%$ & & 20.7 (9.9) & \\
\hline White & $23 \%$ & $29 \%$ & & $27.9(10.4)$ & \\
\hline Season & & & 0.048 & & 0.019 \\
\hline Spring & $42 \%$ & $32 \%$ & & $22.0(10.8)^{*}$ & \\
\hline Summer & $44 \%$ & $26 \%$ & & $23.1(10.8)^{*}$ & \\
\hline Autumn & $16 \%$ & $33 \%$ & & $28.8(9.7)^{*}$ & \\
\hline Winter & $43 \%$ & $36 \%$ & & $23.0(11.7)$ & \\
\hline Fatty fish consumption & & & 0.272 & & 0.605 \\
\hline 0 oz/week & $26 \%$ & $32 \%$ & & $26.8(10.3)$ & \\
\hline 0-3.5 oz/week & $44 \%$ & $26 \%$ & & $22.9(11.0)$ & \\
\hline > $3.5 \mathrm{oz} /$ week & $39 \%$ & $32 \%$ & & $23.5(10.3)$ & \\
\hline Pregnant & & & 0.005 & & 0.016 \\
\hline $\begin{array}{l}\text { Yes White } \\
\text { Black }\end{array}$ & $\begin{array}{l}2610 \% \\
38 \%\end{array}$ & $\begin{array}{l}3536 \% \\
33 \%\end{array}$ & & $\begin{array}{l}25.9(11.3) 30.5(10.6)^{b} \\
22.1(10.6)^{b}\end{array}$ & \\
\hline $\begin{array}{l}\text { No White } \\
\text { Black }\end{array}$ & $\begin{array}{l}4933 \% \\
64 \%\end{array}$ & $\begin{array}{l}2422 \% \\
25 \%\end{array}$ & & $\begin{array}{l}22.6(10.0) 25.8(9.9)^{b} \\
19.5(9.2)^{b}\end{array}$ & \\
\hline Age & & & 0.056 & & 0.014 \\
\hline $18-25$ & $27 \%$ & $29 \%$ & & $27.0(11.6) *$ & \\
\hline$>25-30$ & $37 \%$ & $26 \%$ & & $24.1(10.5)$ & \\
\hline$>30-35$ & $49 \%$ & $34 \%$ & & $20.8(8.6) *$ & \\
\hline$>35$ & $52 \%$ & $30 \%$ & & $20.8(9.5)$ & \\
\hline BMI & & & - & & 0.754 \\
\hline$<18.5$ & - & - & & $29.1(10.0)$ & \\
\hline $18.5-24.99$ & - & - & & $24.8(11.7)$ & \\
\hline 25.29 .99 & - & - & & $22.8(10.5)$ & \\
\hline$>30$ & - & - & & $23.9(10.5)$ & \\
\hline Income & & & 0.579 & & 0.894 \\
\hline$<\$ 10,000$ & $38 \%$ & $33 \%$ & & $23.7(10.1)$ & \\
\hline$>\$ 10,000-\$ 30,000$ & $45 \%$ & $29 \%$ & & $23.3(11.7)$ & \\
\hline$>\$ 30,000$ & $38 \%$ & $21 \%$ & & $24.4(11.1)$ & \\
\hline WIC & & & 0.282 & & 0.120 \\
\hline yes & $35 \%$ & $31 \%$ & & $24.8(10.4)$ & \\
\hline no & $47 \%$ & $26 \%$ & & $22.8(11.3)$ & \\
\hline Education level & & & 0.787 & & 0.946 \\
\hline High school or less & $37 \%$ & $29 \%$ & & $24.2(10.7)$ & \\
\hline Some college/Associate's degree & $42 \%$ & $26 \%$ & & $23.9(11.0)$ & \\
\hline College graduate or higher & $33 \%$ & $44 \%$ & & $25.0(10.1)$ & \\
\hline Alcohol use (drinks/week)- & & & & & 0.146 \\
\hline 14 or more & - & - & & $22.5(12.7)$ & \\
\hline 7 to 13 & - & - & & $26.2(6.8)$ & \\
\hline 4 to 6 & - & - & & $22.6(8.2)$ & \\
\hline 1 to 3 & - & - & & $20.2(10.9)$ & \\
\hline
\end{tabular}


Table 2 Vitamin D status (severe deficiency/moderate deficiency) and mean 25(OH)D levels stratified by characteristics including significance values for bivariate analyses (Continued)

\begin{tabular}{|c|c|c|c|c|c|}
\hline Characteristics & Severe deficiency $(<20 \mathrm{ng} / \mathrm{mL})$ & Moderate deficiency $(21-30 \mathrm{ng} / \mathrm{mL})$ & $p$ & Mean 25(OH)D levels (SD) & $P^{a}$ \\
\hline Less than 1 & - & - & & $27.5(11.0)$ & \\
\hline I didn't drink then & - & - & & $23.9(10.9)$ & \\
\hline Smoking level & & & 0.795 & & 0.445 \\
\hline nonsmoker & $42 \%$ & $28 \%$ & & $23.2(10.7)$ & \\
\hline former & $31 \%$ & $38 \%$ & & $24.8(11.3)$ & \\
\hline $1-10$ cigs/day & $31 \%$ & $28 \%$ & & $26.3(10.7)$ & \\
\hline$>=11$ cigs $/$ day & $38 \%$ & $38 \%$ & & $23.0(10.9)$ & \\
\hline Cotinine & & & 0.013 & & 0.005 \\
\hline High (> 12.9 ng/mL) & $16 \%$ & $24 \%$ & & $29.9(10.7)$ & \\
\hline Low $(<12.9$ ng/mL) & $42 \%$ & $31 \%$ & & $21.8(11.0)$ & \\
\hline Cadmium (median) & & & 0.281 & & 0.482 \\
\hline High $(>0.47 \mu \mathrm{g} / \mathrm{L})$ & $40 \%$ & $33 \%$ & & $23.1(9.8)$ & \\
\hline Low $(<0.47 \mu g / L)$ & $41 \%$ & $24 \%$ & & $24.2(11.3)$ & \\
\hline Lead (median) & & & 0.257 & & 0.211 \\
\hline High (>0.48 $\mu \mathrm{g} / \mathrm{dL})$ & $46 \%$ & $28 \%$ & & $22.6(10.5)$ & \\
\hline $\operatorname{Low}(<0.48 \mu \mathrm{g} / \mathrm{dL})$ & $35 \%$ & $29 \%$ & & $24.7(10.5)$ & \\
\hline Mercury & & & 0.168 & & 0.446 \\
\hline $\operatorname{High}(>5.8 \mu \mathrm{g} / \mathrm{L})$ & $24 \%$ & $47 \%$ & & $25.5(10.1)$ & \\
\hline $\operatorname{Low}(<5.8 \mu \mathrm{g} / \mathrm{L})$ & $42 \%$ & $27 \%$ & & $23.5(10.6)$ & \\
\hline Proximity to coast & & & 0.488 & & 0.875 \\
\hline Zip code proximal to coast & $43 \%$ & $20 \%$ & & $23.8(9.9)$ & \\
\hline Further from coast & $37 \%$ & $31 \%$ & & $24.1(11.1)$ & \\
\hline
\end{tabular}

$P$ values determined by chi-square tests. Differences were considered statistically significant at $p<0.05$, bold type indicates significance $\mathrm{p}^{\mathrm{a}}$ values determined by Independent-Samples T test or one-way ANOVA; significance at $p<0.05$; bold type indicates significance significantly different using Tukey's test

bsignificantly different using Independent-Samples T test

- due to small $\mathrm{n}$ in cells, chi-square test assumptions were not met and could not be performed

Table 3 Spearman's rho bivariate analysis of vitamin D with heavy metals

\begin{tabular}{|c|c|c|c|c|c|}
\hline & Vit D (ng/mL) & $\mathrm{Pb}(\mu \mathrm{g} / \mathrm{dL})$ & $\mathrm{Hg}(\mu \mathrm{g} / \mathrm{L})$ & $\mathrm{Cd}(\mu \mathrm{g} / \mathrm{L})$ & Salivary cotinine $(\mathrm{ng} / \mathrm{mL})$ \\
\hline \multicolumn{6}{|l|}{ Vit $D(n g / m L)$} \\
\hline Correlation Coefficient & 1.000 & & & & \\
\hline Sig. (2-tailed) & & & & & \\
\hline \multicolumn{6}{|l|}{$\mathrm{Pb}(\mu \mathrm{g} / \mathrm{dL})$} \\
\hline Correlation Coefficient & -0.099 & 1.000 & & & \\
\hline Sig. (2-tailed) & 0.196 & & & & \\
\hline \multicolumn{6}{|l|}{$\mathrm{Hg}(\mu \mathrm{g} / \mathrm{L})$} \\
\hline Correlation Coefficient & -0.013 & 0.099 & 1.000 & & \\
\hline Sig. (2-tailed) & 0.865 & 0.199 & . & & \\
\hline \multicolumn{6}{|l|}{$\mathrm{Cd}(\mu \mathrm{g} / \mathrm{L})$} \\
\hline Correlation Coefficient & -0.033 & $0.364^{b}$ & $0.206^{\mathrm{a}}$ & 1.000 & \\
\hline Sig. (2-tailed) & 0.665 & 0.000 & 0.007 & & \\
\hline
\end{tabular}


Table 4 Spearman's rho bivariate analysis of vitamin D with fish and seafood

\begin{tabular}{|c|c|c|c|c|c|c|c|c|}
\hline & 1. & 2. & 3. & 4. & 5. & 6. & 7. & 8. \\
\hline \multicolumn{9}{|l|}{ 1. Vit $D(n g / m L)$} \\
\hline Correlation Coefficient & 1.000 & & & & & & & \\
\hline Sig. (2-tailed) & . & & & & & & & \\
\hline \multicolumn{9}{|l|}{ 2.Fatty fish consumption } \\
\hline in ounces Correlation & -0.118 & 1.000 & & & & & & \\
\hline Coefficient & 0.111 & . & & & & & & \\
\hline \multicolumn{9}{|l|}{ Sig. (2-tailed) } \\
\hline \multicolumn{9}{|l|}{ 3. Shrimp } \\
\hline Correlation Coefficient & -0.119 & $0.212^{b}$ & 1.000 & & & & & \\
\hline Sig. (2-tailed) & 0.125 & 0.006 & . & & & & & \\
\hline \multicolumn{9}{|l|}{ 4. Canned Tuna } \\
\hline Correlation Coefficient & -0.113 & $0.753^{b}$ & $0.284^{b}$ & 1.000 & & & & \\
\hline Sig. (2-tailed) & 0.143 & 0.000 & 0.000 & . & & & & \\
\hline \multicolumn{9}{|l|}{ 5. Crab } \\
\hline Correlation Coefficient & -0.022 & $0.244^{b}$ & $0.713^{a}$ & $0.280^{b}$ & 1.000 & & & \\
\hline Sig. (2-tailed) & 0.782 & 0.002 & 0.000 & 0.000 & & & & \\
\hline \multicolumn{9}{|l|}{ 6. Catfish } \\
\hline Correlation Coefficient & -0.103 & $0.348^{b}$ & $0.304^{b}$ & $0.360^{b}$ & $0.262^{\mathrm{a}}$ & 1.000 & & \\
\hline Sig. (2-tailed) & 0.187 & 0.000 & 0.000 & 0.000 & 0.001 & & & \\
\hline \multicolumn{9}{|l|}{ 7. Crayfish } \\
\hline Correlation Coefficient & -0.036 & $0.386^{\mathrm{b}}$ & $0.370^{\mathrm{a}}$ & $0.325^{\mathrm{b}}$ & $0.447^{\mathrm{a}}$ & $0.199^{\mathrm{a}}$ & 1.000 & \\
\hline Sig. (2-tailed) & 0.648 & 0.000 & 0.000 & 0.000 & 0.000 & 0.012 & . & \\
\hline \multicolumn{9}{|l|}{ 8. Tilapia } \\
\hline Correlation Coefficient & -0.096 & $0.517^{b}$ & $0.234^{b}$ & $0.403^{b}$ & $0.214^{b}$ & $0.377^{b}$ & $0.262^{b}$ & 1.000 \\
\hline Sig. (2-tailed) & 0.220 & 0.000 & 0.002 & 0.000 & 0.007 & 0.000 & 0.001 & . \\
\hline
\end{tabular}

${ }^{a}$ Correlation is significant at the 0.05 level (2-tailed)

${ }^{\mathrm{b}}$ Correlation is significant at the 0.01 level (2-tailed)

previous research conducted among pregnant women in Louisiana, which demonstrated an atypical pattern of seasonal variation [28]. As in this presented data, Gangat et al. observed autumn to be the apex season for serum vitamin $\mathrm{D}$ levels in a similar study population. This atypical seasonal pattern of serum vitamin D levels may be linked to sun avoidance behaviors during the hot and humid summer months in southern Louisiana. Also, there is a high awareness of sun exposure-related skin cancer. Successful campaigns to control sun exposure through sunscreen use and sun avoidance behaviors are currently common in all racial groups and have, in combination with the adoption of lifestyles that have shifted to more time spent indoors, most likely led to increasing prevalence of vitamin D deficiency in the general population $[10,22]$. Louisiana's latitude and relatively high seasonal humidity as compared to other published study locations investigating seasonal variation in U.S. women such as Pennsylvania [46], Washington, North Carolina and Michigan [43] may explain an observed deviation from published season-mediated vitamin D fluctuations in similar research populations.

The more pronounced seasonal variation among Black women suggests sun avoidance behavior during the warm spring and summer seasons may be more common in that group. The large disparity between White and Black women in the winter suggests that the UVB radiation is inadequate in winter months for darker pigmented women to sustain serum vitamin D levels from sun exposure.

\section{Diet}

Fish, especially oily-fish such as salmon, mackerel and bluefish, are considered a good source of vitamin $D_{3}$. Counter to this, consumption of fish considered to be rich in vitamin $D_{3}$, as well as fish and seafood types most frequently consumed by this population, had no influence on vitamin $D_{3}$ levels in this study. There are multiple factors that could explain this. A meta-analysis by Lehman et al., 2015 investigating whether fish intake 
Table 5 Linear regression model for analysis of mean $25(\mathrm{OH}) \mathrm{D}$ levels with race, pregnancy, season, age, WIC status in the study population

\begin{tabular}{ll}
\hline Characteristics & $\beta$ (Cl 95\%) \\
\hline Race & \\
Black & $-6.8(-9.8$ to -3.7$)$ \\
White & Referent \\
Pregnant & \\
Yes & $3.4(0.2$ to 6.6$)$ \\
No & Referent \\
Season & \\
Spring & $-5.7(-10.4$ to -1.0$)$ \\
Summer & $-3.4(-7.1$ to 0.4$)$ \\
Autumn & Referent \\
Winter & $-6.1(-12.5$ to 0.4$)$ \\
Age & \\
18-25 & Referent \\
$>25-30$ & $-3.0(-6.8$ to 0.8$)$ \\
$>30-35$ & $-5.0(-9.2$ to -0.9$)$ \\
$>35$ & $-4.3(-9.2$ to 0.7$)$ \\
WIC & \\
Yes & $2.4(-1.0$ to 5.8$)$ \\
No & Referent \\
\hline
\end{tabular}

$\mathrm{Cl}$, confidence interval increases serum $25(\mathrm{OH})$ vitamin $\mathrm{D}_{3}$ concentrations in healthy adults showed that the consumption of at least 2 fish meals, corresponding to approximately $300 \mathrm{~g} /$ week over a period of at least 4 weeks, was associated with a significant increase in $25(\mathrm{OH})$ vitamin $\mathrm{D}_{3}$ [48]. In the GROWH subpopulation of this study, fish consumption was analyzed in ounces per week (Table 1.) which shows that the majority of women (76\%) consumed $3.5 \mathrm{oz}$ (= $85 \mathrm{~g}$ ) of fish or less per week.

The aforementioned meta-analysis also showed that the type of fish is an important factor, with fatty fish consumption improving vitamin $\mathrm{D}_{3}$ status. Fatty fish consumption was not popular in this population sample, which may explain why fish consumption had a non-significance influence over systemic vitamin D levels. The seafood most consumed by this study population was crustaceans such as shrimp which contains little to no vitamin $\mathrm{D}$ and therefore has little influence on overall serum vitamin $\mathrm{D}_{3}$ concentrations. Drewery et al., 2016 also found that while catfish and tilapia were regularly consumed among pregnant women in Louisiana, seafood sources with higher fatty acids content were consumed at a low frequency [49]. Chen et al., 2007 evaluated the effect of various cooking methods on the vitamin $\mathrm{D}_{3}$ content of food. While microwaving or baking has not been shown to decrease vitamin $\mathrm{D}_{3}$ content significantly, when frying salmon in vegetable oil, only about half of the vitamin $D_{3}$ was recovered [50]. Fry cooking seafood in oil is a popular food preparation method in southeastern Louisiana.

Furthermore, Liu (2012) found that although mushrooms, eggs, and oily fish may potentially contain high
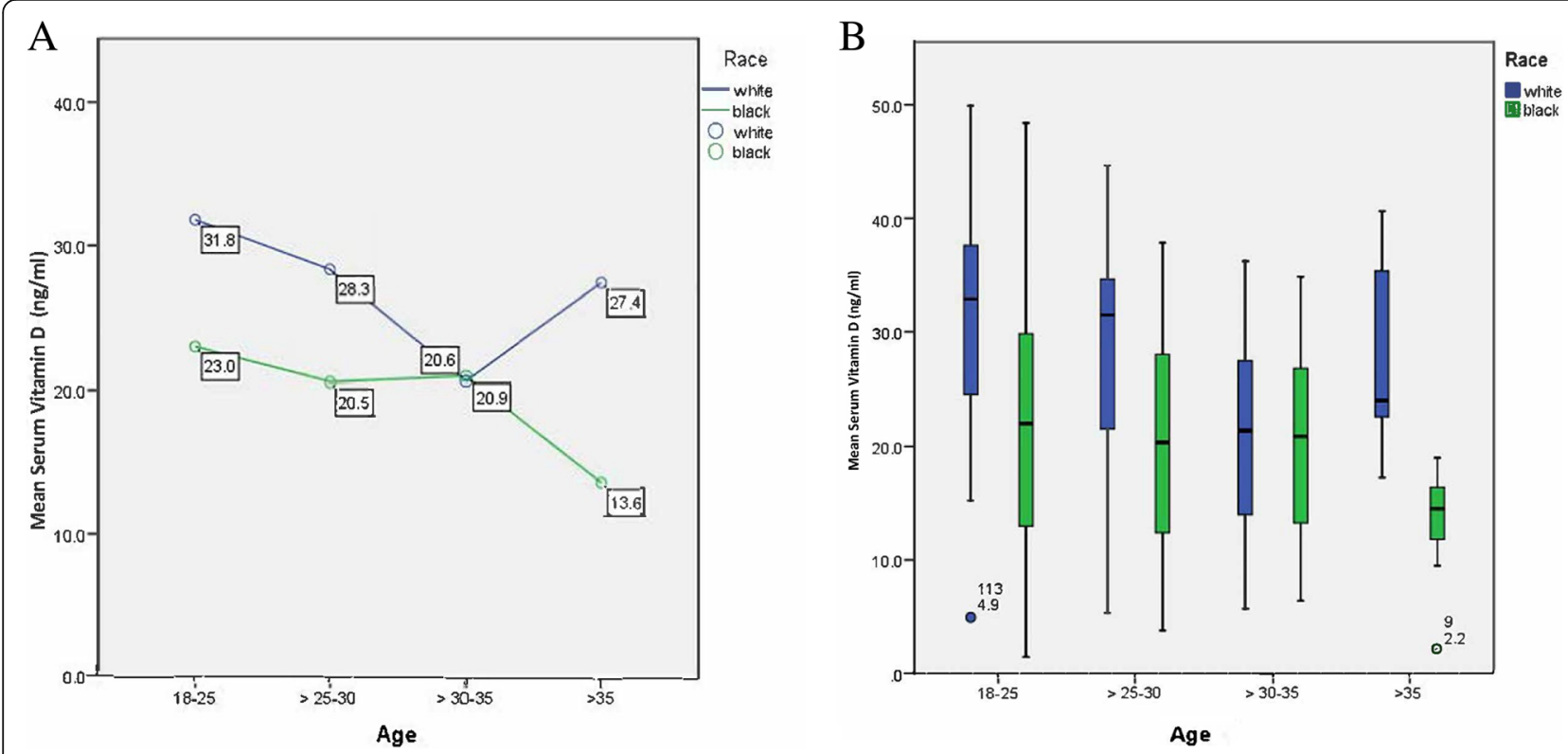

Fig. $\mathbf{3}$ a and $\mathbf{b}$ The influence of race and age on mean serum vitamin $D_{3}$ levels in surveyed women 

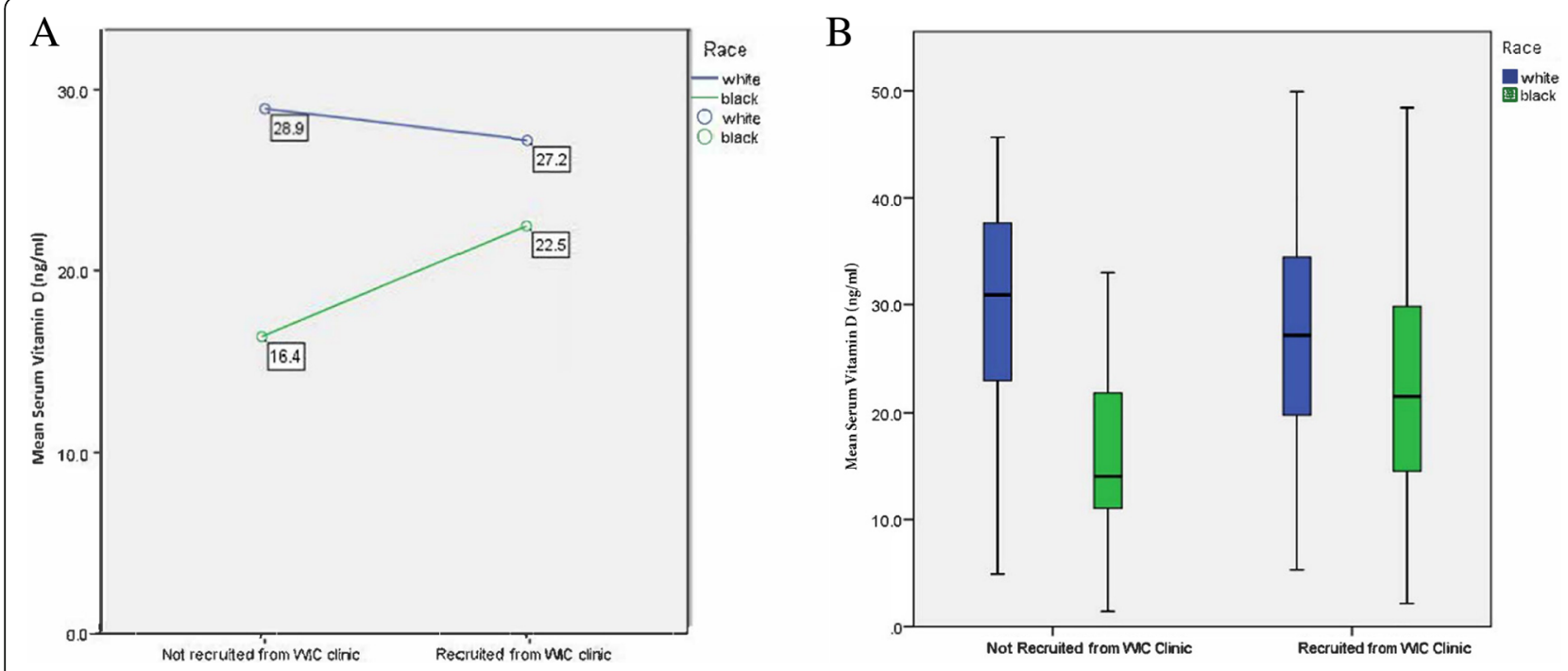

Fig. $4 \mathbf{a}$ and $\mathbf{b}$ The influence of race and location of recruitment site on mean serum vitamin $D_{3}$ levels in surveyed women

concentrations of vitamin $D_{3}$, these foods may provide an unreliable source of vitamin $\mathrm{D}_{3}$ or are not eaten in large enough amounts to significantly impact serum vitamin D status. Lui's study, therefore, concluded that systemic vitamin $\mathrm{D}_{3}$ levels are primarily modulated by UV exposure and/or oral supplementation [51]. Although fish is one of the few foods that contain vitamin $D_{3}$, there is still an ongoing discussion about whether fish intake contributes to a sufficient supply of vitamin $\mathrm{D}_{3}[48]$.

\section{Pregnancy}

Higher $25(\mathrm{OH})$ vitamin $\mathrm{D}_{3}$ concentrations in pregnant women could be due to prenatal supplementation which is advised for pregnant women. While there is no data available for the GROWH participants on compliance to prenatal vitamin's or on which type of prenatal vitamins were being used (and whether they contained vitamin $\mathrm{D}_{3}$ ), in similar populations, more than $90 \%$ of pregnant women reported using prenatal vitamins [34]. Although the focus of prenatal vitamins is predominantly on folic
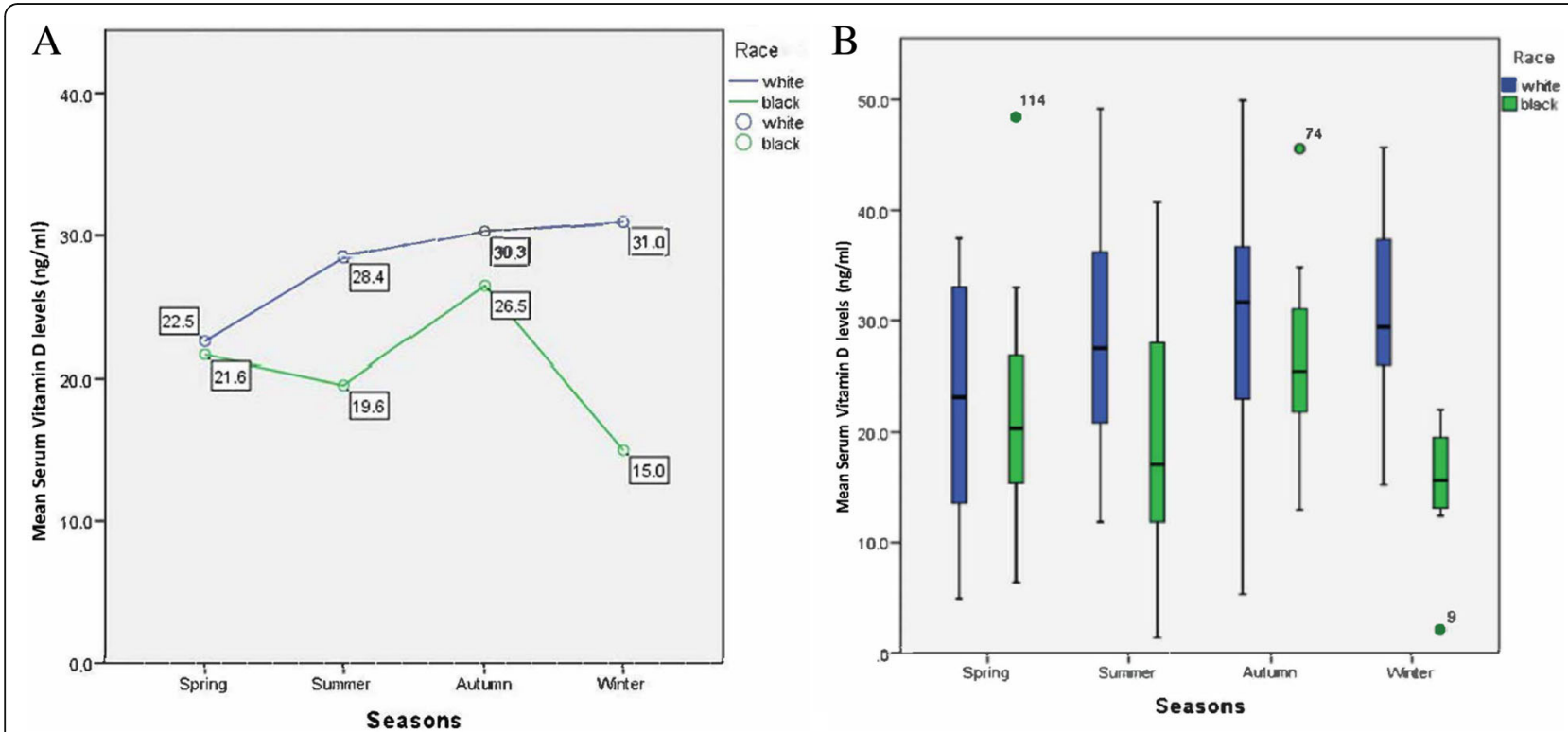

Fig. $\mathbf{5}$ a and $\mathbf{b}$ The influence of race and seasonality on mean serum vitamin $D_{3}$ levels in surveyed women 
acid, iron, and calcium, most of them also contain around 400-600 IU vitamin $\mathrm{D}_{3}$ [25] and have shown to increase vitamin $\mathrm{D}$ status as pregnant women tend to have higher $25(\mathrm{OH}) \mathrm{D}_{3}$ levels than non-pregnant women [24, 52]. Ginde et al. 2010 showed that the mean $25(\mathrm{OH}) \mathrm{D}_{3}$ levels by increasing trimester were 46,46 , and $54 \mathrm{nmol} / \mathrm{L}$, respectively, among women not taking vitamin $\mathrm{D}$-containing supplements $(P$ for trend $=.27$ ), compared to 61,69 , and $84 \mathrm{nmol} / \mathrm{L}$ among those taking supplements $(P$ for trend $<.001)$.

A randomized control trial by Hollis et al. 2011, examining the need, safety and effectiveness of vitamin D supplementation during pregnancy showed that, compared to the $400 \mathrm{IU}$ group (control), a daily vitamin D dose of $2000 \mathrm{IU}$ and $4000 \mathrm{IU}$ was associated with improved serum vitamin $\mathrm{D}_{3}$ status throughout the pregnancy, one month prior, and at delivery in both mother and neonate [52].

Vitamin D binding protein (VDBP) could possibly be playing a role in higher serum $25(\mathrm{OH})$ vitamin $\mathrm{D}_{3}$ levels in pregnant women. Because of the estrogen-dependent production of VDBP, pregnant women have been observed to have increased serum concentrations of vitamin D [53]. It is uncertain how much this innate biological response contributes to observed higher serum 25(OH) vitamin $\mathrm{D}_{3}$ levels in our study population.

\section{Other factors}

Other influencing factors include tobacco exposure (measured by salivary cotinine), age and WIC participation. Interestingly, high cotinine $(>12.9 \mathrm{ng} / \mathrm{mL})$ was associated with higher vitamin $\mathrm{D}_{3}$ levels for which we do not have a clear explanation. Possibly, the behavior of going outside to smoke and the strong influence of sun exposure on vitamin $D_{3}$ synthesis might contribute to this observation. However, other research shows a negative correlation between smoking and vitamin D levels which could possibly be explained by the fact that smoking is usually accompanied by a less healthy lifestyle (less physical activity, alcohol consumption, and bad dietary habits) leading to reduced sun exposure and thus synthesis of vitamin D. A causative role of smoking in vitamin D deficiency could not be excluded but the mechanism that explains the effect of cigarette smoking in vitamin D metabolism remains unclear $[40,54,55]$.

In other studies, younger age was associated with lower vitamin $\mathrm{D}_{3}$ levels in pregnancy, due to vitamin supplementation being more common among older women, suggesting that younger individuals may be less conscientious about health matters [26, 27]. Our study, however, showed higher serum $25(\mathrm{OH}) \mathrm{D}_{3}$ levels among the youngest age group (18-25 years). Older age might be related to more education and higher income, which have been associated with more employment indoors [26].

In White women, mean serum $25(\mathrm{OH}) \mathrm{D}_{3}$ levels abruptly decreased at age category $30-35$, and a strong decrease was observed in Black women at age category $>35$. Possibly, the high number of non-pregnant women in these age groups decreased the mean serum $25(\mathrm{OH})$ $\mathrm{D}_{3}$ concentrations. Non-pregnant women most likely have stopped taking prenatal vitamins as they are per definition labeled as "prenatal."

While WIC participation was not significantly associated with vitamin D status in White women, Black women from WIC clinics had significantly higher serum vitamin $\mathrm{D}_{3}$ levels compared to Black women who were not recruited from WIC clinics. Although this study was not a controlled trial, this observation suggests that participation in the federally-funded WIC program improves nutrition-related health outcomes such as serum vitamin $\mathrm{D}_{3}$ deficiency in some populations of Black women. As an overall higher level of deficiency generally exists in Black women, small behavioral and dietary modifications may lead to relatively greater improvement in vitamin D levels. Although WIC participation has shown improvements in other outcomes such as infant mortality in Black/African American populations [56, 57], to our knowledge, this is the first study assessing the impact of WIC enrollment on serum $25(\mathrm{OH}) \mathrm{D}_{3}$.

A unique public health policy of universal vitamin D supplementations for all pregnant and lactating women and all children under 5 years of age, called the Heart of Birmingham Primary Care Trust, was implemented in Birmingham, UK in 2005 in response to an increasing resurgence of symptomatic cases of vitamin D deficiency in a high-risk predominantly ethnic minority population [58]. This universal program has reduced the cases of symptomatic vitamin D deficiency and has increased public awareness of vitamin $\mathrm{D}$ demonstrating that public health campaigns to tackle vitamin D deficiency through supplementation and nutritional education can be effective.

\section{Limitations}

This study has several limitations that influence the generalizability of the results. This study was unable to collect data on daily sun exposure, sun avoidance behavior or outdoor physical activity. Although vitamin D (prenatal) intake was likely due to observed increased levels of serum vitamin D in pregnant women as compared to their non-pregnant counterparts, prenatal vitamin intake compliance was not quantified directly. Also, as a control for inter-racial differences in serum vitamin $\mathrm{D}$ binding protein, future studies might consider determining the role vitamin $\mathrm{D}$ binding protein has on serum 
vitamin $\mathrm{D}$ levels in similar populations. Although the $25(\mathrm{OH})$ vitamin $\mathrm{D}_{3}$ quantification methods utilized in this study are not certified by the Vitamin D Standardization Program (VDSP), immunoassay methods such as utilized in this study are employed by $97 \%$ of clinical laboratories. Also, given the cross-sectional and observational nature of the study, we were unable to draw hard conclusions about the observed effect such as vitamin D status improvement due to WIC enrollment.

Finally, the small sample size limited the statistical power and methods that could be applied to investigate interactions between multiple covariates. For example, the cotinine variable could not be incorporated into the multiple regression model due to an insufficient number of available samples.

\section{Conclusion}

Vitamin D deficiency is common among low-income, reproductive-aged women living along the coast of southeastern Louisiana, which adds to a growing body of research showing inadequate serum vitamin $D_{3}$ levels in reproductive-aged women worldwide. In this study, women at highest risk for vitamin $\mathrm{D}_{3}$ deficiency self-identified as Black and were non-WIC participants greater than 35 years of age. The winter season exacerbated vitamin $\mathrm{D}_{3}$ deficiency in this group of women. Interventions to improve vitamin $\mathrm{D}_{3}$ status are feasible and should be implemented to encourage dietary changes including healthy fish consumption, vitamin $\mathrm{D}_{3}$ supplementation, and safe sun exposure. Improving serum vitamin $\mathrm{D}_{3}$ status among this population may reduce adverse reproductive outcomes. Further studies are warranted to fully elucidate potential associations between serum vitamin $D_{3}$ status and reproductive outcomes.

\section{Abbreviations \\ CDC: Centers for disease control; ELISA: Enzyme-linked immune sorbent Assay; EPA: US Environmental Protection Agency; GROWH: Gulf Resilience on Women's Health; ICP-MS: Inductively coupled plasma-mass spectrometry; OSHA: Occupational Safety and Health Administration; PRAMS: Pregnancy Risk Assessment Monitoring; SGA: Small for Gestational Age; WIC: Women, Infants, and Children}

\section{Acknowledgments}

Research reported in this publication was supported by the National Institute of Environmental Health Sciences under Award Number U19ES020677 and the Fogarty International Center under Award Number U2RTW010104 of the National Institutes of Health. The content is solely the responsibility of the authors and does not necessarily represent the official views of the National Institutes of Health. This research was also partially supported by the Baton Rouge Area Foundation under a grant entitled, Risk and Resilience in Environmental Health".

\section{Funding}

Research reported in this publication was supported by the National Institute of Environmental Health Sciences of the National Institutes of Health under Award Number U19ES020677. The content is solely the responsibility of the authors and does not necessarily represent the official views of the National Institutes of Health.

\section{Availability of data and materials}

Requests for data and material presented in this manuscript can be accommodated via written inquiry to the corresponding author.

\section{Authors' contributions}

MM,NB: conceived the study and manuscript. MM,NB,AS, JW: interpreted and analyzed data. MM,EH,NB: conducted quality control of the analysis of primary and secondary data. $\mathrm{ML}, \mathrm{MM}, \mathrm{EH}, \mathrm{NB}$, created and merged databases from primary survey, and biomarker studies. ML: performed initial Louisiana study, and provided data interpretation support. All authors contributed to the writing and read and approved the final manuscript.

\section{Ethics approval and consent to participate}

Tulane University Institutional Review Board (IRB) approved the study, IRB protocol number 239911, and written informed consent was obtained from all the participants.

\section{Competing interests}

The authors declare they have no competing interests.

\section{Publisher's Note}

Springer Nature remains neutral with regard to jurisdictional claims in published maps and institutional affiliations.

\section{Author details}

'Department of Global Environmental Health Sciences, Tulane University School of Public Health and Tropical Medicine, 1440 Canal Street, Suite 2100, New Orleans, Louisiana 70112, USA. ${ }^{2}$ Department of Epidemiology, Tulane University School of Public Health and Tropical Medicine, 1440 Canal Street, Suite 2001, New Orleans, LA 70112, USA. ${ }^{3}$ Department of Global Biostatistics and Data Science, Tulane University School of Public Health and Tropical Medicine, 1440 Canal St, Room 2007, New Orleans, LA 70112, USA.

Received: 9 April 2018 Accepted: 15 March 2019

Published online: 02 April 2019

\section{References}

1. Holick MF. Vitamin D deficiency. N Engl J Med. 2007;357:266-81.

2. Holick MF, Chen TC. Vitamin D deficiency: a worldwide problem with health consequences. Am J Clin Nutr. 2008;87(Suppl):1080S-6S.

3. Garland CF, Kim JJ, Mohr SB, Gorham ED, Grant WB, Giovannucci EL, et al. Meta-analysis of all-cause mortality according to serum 25-hydroxyvitamin D. Am J Public Health. 2014;104(8):e43-50.

4. Palacios C, Gonzalez L. Is vitamin D deficiency a major global public health problem? J Steroid Biochem Mol Biol. 2014;144 Pt A:138-45.

5. Bischoff-Ferrari HA, Giovannucci E, Willet W, Dietrich T, Dawson-Hughes B. Estimation of optimal serum concentrations of 25-hydroxyvitamin $D$ for multiple health outcomes. Am J Clin Nutr. 2006;84(1):18-28.

6. Schwalfenberg GK. A review of the critical role of vitamin $D$ in the functioning of the immune system and the clinical implications of vitamin D deficiency. Mol Nutr Food Res. 2011;55:96-100.

7. Vieth $R$. Why the optimal requirement for vitamin $D_{3}$ is probably much higher than what is officially recommended for adults. J Steroid Biochem Mol Biol. 2004;89-90(1-5):575-9.

8. Uriu-Adams JY, Obican SG, Keen CL. Vitamin D and maternal and child health: overview and implications for dietary requirements. Birth Defects Res. 2013;99:22-44.

9. Hollis BW, Wagner CL. Vitamin D and pregnancy: skeletal effects, nonskeletel effects and birth outcomes. Calcif Tissue Int. 2013;92(2):123-39.

10. Bodnar LM, Simhan HN. Vitamin D may be a link to black-white disparities in adverse birth outcomes. Obstet Gynecol Surv. 2010;65(4):273-84.

11. Bodnar LM, Catov JM, Simhan HN, Holick MF, Powers RW, Roberts JM. Maternal vitamin $\mathrm{D}$ deficiency increases the risk of preeclampsia. J Clin Endocrinol Metab. 2007;92(9):3517-22.

12. Baker AM, Haeri S, Camargo CA Jr, Espinola JA, Stuebe AM. A nested casecontrol study of midgestation vitamin D deficiency and risk of severe preeclampsia. J Clin Endocrinol Metab. 2010;95(11):5105-9.

13. Robinson CJ, Alanis MC, Wagner CL, Hollis BW, Johnson DD. Plasma 25hydroxyvitamin $\mathrm{D}$ levels in early-onset severe preeclampsia. Am J Obstet Gynecol. 2010;203(4):e361-6. 
14. Wei SQ, Audibert F, Hidiroglou N, et al. Longitudinal vitamin D status in pregnancy and the risk of pre-eclampsia. BJOG. 2012;119:832-9. https://doi.org/10.1111/j.1471-0528.2012.03307.x.

15. Lau SL, Gunton JE, Athayde NP, Byth K, Cheung NW. Serum 25hydroxyvitamin D and glycated haemoglobin levels in women with gestational diabetes mellitus. Med J Aust. 2011;194(7):334-7.

16. Leffelaar ER, Vrijkotte TG, van Eijsden M. Maternal early pregnancy vitamin D status in relation to fetal and neonatal growth: results for the multi-ethnic Amsterdam born children and their development cohort. Br J Nutr. 2010;104(1):108-17.

17. Williams JA, Romero VC, Clinton CM, Vazquiz DM, Marcus SM, Chilimigras JL, et al. Vitamin D levels and perinatal depressive symptoms in women at risk: a secondary analysis of the mothers, omega-3, and mental health study. BMC Pregnancy and Childbirth. 2016;16:203.

18. Mazahery H, Camargo CA, Conlon C, Beck KL, Kruger MC, von Hurst PR. Vitamin D and Autism Spectrum Disorder: A Literature Review. Nutrients. 2016;8(4):236.

19. Hollis BW. Assessment of vitamin D nutritional and hormonal status: what to measure and how to do it. Calcif Tissue Int. 1996;58:4-5.

20. Holick MF, Binkley NC, Bischoff-Ferrari HA, Gordon CM, Hanley DA, Heaney RP, Murad MH, Weaver CM, Endocrine Society. Evaluation, treatment, and prevention of vitamin D deficiency: an Endocrine Society clinical practice guideline. J Clin Endocrinol Metab. 2011;96(7):1911-30.

21. van den Ouweland JM, Vogeser M, Bächer S. Vitamin D and metabolites measurement by tandem mass spectrometry. Rev Endocr Metab Disord. 2013;14(2):159-84.

22. Chen TC, Chimeh F, Lu Z, Mathieau J, Person KS, Zhang A, Kohn N, Marinello S, Berkowitz R, Holick MF. Factors that influence the cutaneous synthesis and dietary sources of vitamin D. Arch Biochem Biophys. 2007;460(2):213-7.

23. Clemens TL, Adams JS, Henderson SL, Holick MF. Increased skin pigment reduces the capacity of skin to synthesize vitamin $D_{3}$. Lancet. 1982;1(8263):74-6.

24. Ginde AA, Sullivan AF, Mansbach JM, Camargo CA. Vitamin D insufficiency in pregnant and nonpregnant women of childbearing age in the United states. Am J Obstet Gynecol. 2010;202(5):436.e1-8.

25. Institute of Medicine. Dietary reference intakes for calcium and vitamin D. Washington, DC: The National Academies Press; 2011. https://doi.org/10.17226/13050

26. Al-Faris NA. High prevalence of vitamin D deficiency among pregnant saudi women. Nutrients. 2016;8(2):77.

27. Rodriquez A, Marina LS, Jimenez AM, Espulugues A, Ballester F, Espada M, et al. Vitamin D status in pregnancy and determinants in a southern European cohort study. Paediatr Perinat Epidemiol. 2016;30:217-28.

28. Gangat M, Tulasi Ponnapakkam T, Bradford E, Katikaneni R, Gensure R. Reversed seasonal variation in maternal vitamin $D$ levels in southern Louisiana. Clin Pediatr. 2012;51(8):718-22.

29. Harville E, Jacobs M, Boynton-Jarrett R. When is exposure to a natural disaster traumatic? Comparison of a trauma questionnaire and disaster exposure inventory. PLoS One. 2015;10(4):1-11.

30. Lichtveld M, Sherchan S, Gam K, Kwok R, Mundorf C, Shankar A, et al. The Deepwater horizon oil spill through the Lens of human health and the ecosystem. Curr Environ Health Rep. 2016;4:370-8.

31. Gulf Resilience on Women's Health (GROWH), http://www. gulfcoastenvironmentalhealth.com/projects/3. Accessed 7 Apr 2017.

32. Oliveira V, Frazão E. The WIC Program: Background, Trends, and Economic Issues, 2009. In: US Department of Agriculture, Economic Research Service. Washington, DC: Economic Research Report No 73; 2009.

33. Norris FH, Friedman MJ, Watson PJ. 60,000 disaster victims speak: Part II. Summary and implications. Psychiatry. 2002;65(3):240-60re.

34. Harville EW, Giarratano G, Savage J, de Mendoza VB, Zotkiewicz T. Birth Outcomes in a Disaster Recovery Environment: New Orleans Women After Katrina. Matern Child Health J. 2015. https://doi.org/10.1007/s10995-015-1772-4.

35. Moreno JA, Yeomans EC, Streifel KM, Brattin BL, Taylor RJ, Tjalkens RB. Agedependent susceptibility to manganese-induced neurological dysfunction. Toxicol Sci. 2009. https://doi.org/10.1093/toxsci/kfp220.

36. Park S, Johnson MA. Awareness of Fish advisories and Mercury Exposure in Women of childbearing age. Nutr Rev. 2006;:250-6.
37. Us environmental protection Agency. Mercury update: Impact on Fish Advisories 2001. Accessed 24 Apr 2017.

38. Stagierowics J, Mikolajewska K, Zawadzjka-Stolarz M, Polanska K, Ligocka D. Estimation of cutoff values of cotinine in urine and saliva for pregnant women in Poland. Biomed Res Int. 2013:1-11.

39. Vieth $\mathrm{R}$. What is the optimal vitamin D status for health? Progress in Biophysics \& Molecular Biology. 2006;92:26-32.

40. Kassi EN, Stavropoulos S, Kokkoris P, Galanos A, Moutsatsou P, Dimas C, et al. Smoking is a significant determinant of low serum vitamin $D$ in young and middle-aged healthy males. HORMONES. 2015. https://doi.org/10.14310/horm.2002.1521.

41. Mina K, Fritschi L, Knuiman M. A valid semiquantitative food frequency questionnaire to measure fish consumption. Eur J Clin Nutr. 2007;61 (8): 1023-31 Epub 2007 Feb 14.

42. Champagne CM, Bogle ML, McGee BB, Yadrick K, Allen HR, Kramer TR, Simpson P, Gossett J, Weber J. Lower Mississippi Delta Nutrition Intervention Research Initiative (2004). Dietary intake in the lower Mississippi delta region: results from the Foods of our Delta Study. J Am Diet Assoc. 2004;104(2):199-207.

43. Luque-fernandez MA, Gelaye B, Vander Weele T, Ferre C, Siega-Riz AM, Holzman C, et al. Seasonal variation of 25-Hydroxyctiamin-D among nonhispanic black and white pregnant women from three U.S. pregnancy cohorts. Paediatric Perinatal Epidemiology. 2014;28(2):166-77.

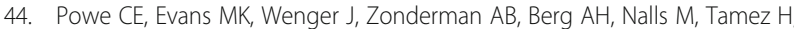
et al. Vitamin D-binding protein and vitamin D status of black Americans and white Americans. N Engl J Med. 2013;369(21):1991-2000.

45. Aloia J, Mikhail M, Dhaliwal R, Shieh A, Usera G, Stolberg A, et al. Islam free 25(OH)D and the vitamin D paradox in African Americans. J Clin Endocrinol Metab. 2015;100(9):3356-63.

46. Bodnar LM, Simhan HN, Powers RW, Frank MP, Cooperstein E, Roberts JM. High prevalence of vitamin D insufficiency in black and white pregnant women residing in the northern United States and their neonates. J Nutr. 2006:447-52.

47. Lundqvist A, Sandstrom H, Stenlund H, Johansson I, Hultdin J. Vitamin D status during pregnancy: A Longitudinal Study in Swedish Women from Early Pregnancy to Seven Months postpartum. PLos One. 2016:e0150385.

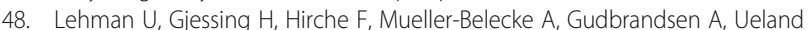
$M$, et al. Efficacy of fish intake on vitamin D status: a meta-analysis of randomized controlled trials. Am J Clin Nutr. 2015;102:837-47.

49. Drewery ML, Gaitan AV, Thaxton C, Xu W, Lammi-Keefe CJ. Pregnant women in Louisiana are not meeting dietary seafood recommendations. J Pregnancy. 2016;2016:1853935. https://doi.org/10.1155/2016/1853935.

50. Chen TC, Chimeh F, Lu Z, Mathieu J, Person KS, Zhang A, et al. Factors that influence the cutaneous synthesis and dietary sources of vitamin D. 2007; 460(2):213-7.

51. Liu J. Vitamin D content of food and its contribution to vitamin D status: a brief overview and Australian focus; 2012. https://doi.org/10.1039/c2pp25150g.

52. Hollis BW, Johnson D, Hulsey TC, Ebeling M, Wagner CL. Vitamin D supplementation during pregnancy: a double-blind, randomized clinical trial of safety and effectiveness. J Bone Miner Res. 2011;26(10):2341-57. https://doi.org/10.1002/jbmr.463.

53. Heijboer AC, Blankenstein MA, Kema IP, Buijs MM. Accuracy of 6 Routine 25Hydroxyvitamin D Assays: Influence of Vitamin D Binding Protein Concentration. Clinical Chemistry. 2012;58:3 543-8.

54. Cutillas-Marco E, Fuertes-Prosper A, Grant WB, Morales-Suárez-Varela M. Vitamin D deficiency in South Europe: effect of smoking and aging. Photodermatology, Photoimmunology \& Photomedicine. 2012:28:159-161 159.

55. Brot $C$, Jùrgensen NR, Helmer Sùrensen $\mathrm{O}$. The influence of smoking on vitamin D status and calcium metabolism. Eur J Clin Nutr. 1999:53:920-6.

56. Khanani I, Elam J, Hearn R, Jones C, Maseru N. The impact of prenatal WIC participation on infant mortality and racial disparities. 2010;\$204-9.

57. Shamberger RJ. Autism rates associated with nutrition and the WIC program. J Am Coll Nutr. 2011;30(5):348-53. https://doi.org/10.1080/07315724.2011.10719978.

58. Moy RJ, McGee E, Debelle GD, Mather I, Shaw NJ. Successful public health action to reduce the incidence of symptomatic vitamin D deficiency. 2012; 97(11):952-4. 